\title{
WHITE DUST SIMULATION FOR TAILINGS POND OF ERDENET COPPER MINING USING HYSPLIT
}

\author{
Lkhagvajargal B. ${ }^{1}$, Sonomdagva $C h .{ }^{I *}$, Byambatseren Ch. ${ }^{1}$, Batdelger $B .{ }^{1,2}$ \\ ${ }^{1}$ Department of Environment and Forest Engineering, School of Engineering and Applied Sciences, \\ National University of Mongolia, Mongolia \\ ${ }^{2}$ Institute of Nature and Environmental Technology, Kanazawa University, Ishikawa, Japan \\ *corresponding author, mail: ch_sonomdagva@num.edu.mn
}

ARTICLE INFO: Received: 10 Nov, 2017; Revised: 13 Dec, 2017; Accepted: 22 Dec, 2017

\begin{abstract}
The purpose of this research was to identify dispersion and transporting of white dust for tailings pond of Erdenet copper mining in Mongolia. Spring and autumn have a significantly higher level of PM10 mass concentration in Erdenet city. Probably caused by the stagnant atmosphere which leads to pollution's cumulative effect and 'white dust' from the storage of tailings pond in spring and autumn. We used meteorological data for 2015 gathered from Information and Research Institute of Meteorology, Hydrology and Environment (IRIMHE) in Erdenet city and GDAS meteorological data provided by U.S NOAA. In the present study, white dust simulation by using the ArcGIS, HYSPLIT program modeling. The Hybrid Single-Particle Lagrangian Integrated Trajectory (HYSPLIT) model is used to identify the white dust dispersion and transportation trends. According to the simulation from model HYSPLIT, white dust was spread between 14 and $65 \mathrm{~km}$ in 2015. The main month of white dust distribution was May and October when mass concentration of PM10 was high due to white dust. White dust distribution was four times lower when the rainy day.
\end{abstract}

Keywords: white dust; trajectories; dispersion; HYSPLIT; tailings pond; Erdenet copper mining;

\section{INTRODUCTION}

The rapid industrialization, urbanization and increasing population bring major environmental pollution problems associated with air pollution. The scientific interest has been driven by the diverse effects mineral dust has on climate and the environment. Crustal aerosols have an influence on the atmospheric radiation balance through scattering and absorption processes [14, 23] and acting as cloud condensation nuclei [29]. Moreover, mineral dust can also make an important contribution to the levels of suspended particulate matter (SPM) recorded in air quality monitoring networks. Dust particles can also act as reaction surfaces for reactive gas species [6, 16 and 24].
There are many drawbacks with the dust phenomenon such as environmental, socio-economic, human health, climate and microclimate problems [12]. Some of these issues are discussed as follows. Wind-blown dust is an effective factor for the transport of pathogens and pollutants $[22,26]$ and also can influence air quality downwind of dust source regions by reducing visibility, soiling property and causing illnesses $[4,19]$.

Inhalation of dust particles can cause heart beat irregularities, heart attacks and respiratory problems, severe and chronic headaches, severe allergies and skin diseases [13]. Particles such as mineral dust, by absorbing ultraviolet radiation can inhibit smog production, having 
profound implications in the control of air pollution in urban areas [7]. Furthermore, the interactions between windblown dust and anthropogenic pollutants aggravate the generation of secondary aerosols [2].

Different Techniques have been developed to identify dust hotspots and pathways.

Numerical modeling, trajectory analysis, Remote sensing and satellite imagery, dust observations and metrological data analysis, mineral tracers and geological models can be applied as the principal tools used to research dust events [8, 11, 12 and 28].

Erdenet, one of the biggest cities in Mongolia and has several mining and industrial companies. By 2015 statistics, population within the city was counted at 100731 inhabitants in Erdenet city [21]. The population is increasing, and due to manufacturing and its' pollution of city air quality has been above the standard limit for the last three years [20]. In October 2015, mass concentration of PM10 was reached $321 \mu \mathrm{g} / \mathrm{m}^{3}$ in Erdenet city. It's about 3.2 times higher than the Mongolian ambient air quality standard (AQS). In May 2015, mass concentration of PM10 was reached $266 \mu \mathrm{g} / \mathrm{m}^{3}$ and it's about 4.1 times higher than Mongolian AQS [17].

Spring and autumn have a significantly

\section{MATERIALS AND METHODS}

\section{Study area}

Erdenet copper molybdenum mine tailings pond is located northeast of Erdenet city (Fig.1). Tailings pond has accounted for 1712.8 hectares of land. Area of sands, slimes and wastewater are expanding at Disposal every year. In 2017, there are 331.1 hectares of wet part, 1345.7 hectares of dried part in tailings pond (Fig.2).

\section{HYSPLIT model description}

The HYSPLIT model uses puff or particle approaches to compute trajectories, complex dispersion and deposition. The model computation method is a combination of Eulerian (concentrations are calculated for each higher level of PM10 mass concentration in Erdenet city. Probably caused by the stagnant atmosphere which leads to pollution's cumulative effect and 'white dust' from the storage of tailings pond in spring and autumn.

One of the main pollution sources of heavy metals and trace elements within the Erdenet Mining Corporation environment is the white dust from the storage of tailings pond. In 2006, there are 500 million tons sands, 25 million $\mathrm{m}^{3}$ wastewater accumulated in tailings pond [15]. Chromium (Cr) from 6.9 to $13.1 \mathrm{mg} / \mathrm{kg}$, arsenic (As) from 9.3 to $10.7 \mathrm{mg} / \mathrm{kg}$, lead $(\mathrm{Pb})$ from 0.2 to $2.3 \mathrm{mg} / \mathrm{kg}$, and copper $(\mathrm{Cu})$ from 61.4 to $96.1 \mathrm{mg} / \mathrm{kg}$ were detected in tailings and filtration pond sediment samples [5].

The White dust resulted from the mining process of Erdenet Mining Corporation is a fine dust, moves around when the wind speed is $5.4 \mathrm{~m} / \mathrm{sec}$ or more landing on soil. Households, animals, plant near the industrial area is faced with the risk of being exposed to heavy metal and negative effect upon their health in the long run has been proven [15].

Some studies have been conducted on white dust characteristics, but there is no study on transport and distribution. Therefore, it is necessary to estimate the distribution of white dust.

grid cell using integration of pollutant fluxes at every grid cell interface due to advection and diffusion) and Lagrangian (concentrations are computed by summing the contribution of each pollutant "puff" that is advocated through the grid cell as represented by its trajectory) approaches.

The model utilizes meshed meteorological data on one of three conformal map projections (Polar, Lambert and Mercator). The dispersion model requires meteorological data fields that can be obtained from archives or from forecast model outputs and the datasets should be formatted for input to HYSPLIT $[9,10]$.

The accuracy of the model is considerably 


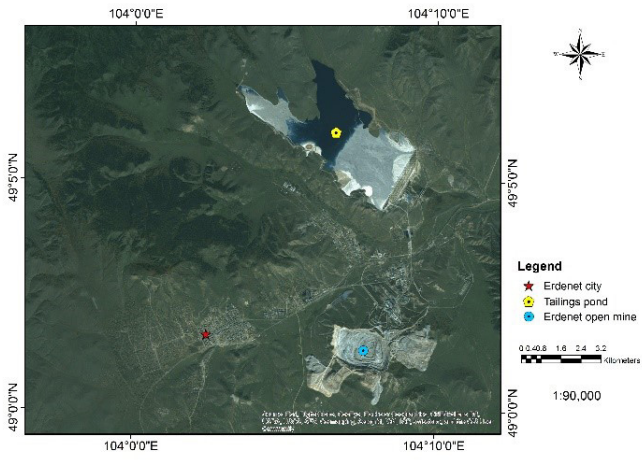

Fig. 1. Study area

dependent on the meteorological data resolution [3]. For this study, we used daily meteorological data, including precipitation, wind velocity, humanity and temperature, was gleaned from a weather station in Erdenet, which is attached to the Information and

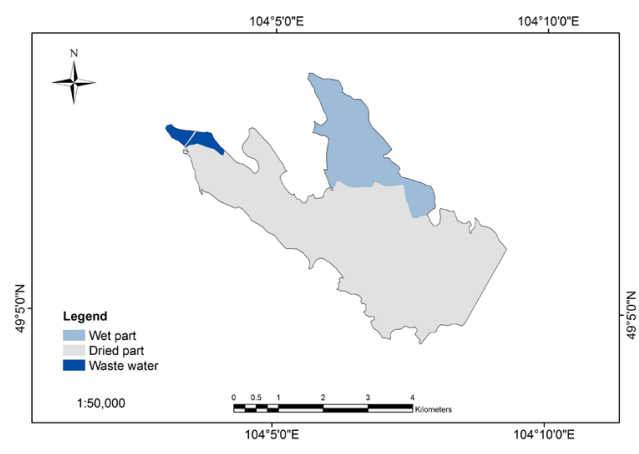

Fig. 2. The classification of the tailings pond

Research Institute of Meteorology, Hydrology and Environment (IRIMHE) and GDAS meteorological data provided by U.S. NOAA. We chose the windiest day during the month and then modeled in those days.

Table 1. Windiest days

\begin{tabular}{|l|c|c|c|c|c|c|}
\hline \multicolumn{1}{|c|}{ Month } & Jan & Feb & Mar & Apr & May & Jun \\
\hline Days & 22 & 14 & 20 & 22 & 12 & 29 \\
\hline Max wind speed, m/s & 13 & 10 & 14 & 16 & 17 & 10 \\
\hline Average wind speed, m/s & 6.9 & 5.5 & 7.6 & 9.3 & 8.8 & 8.3 \\
\hline \multicolumn{1}{|c|}{ Month } & Jul & Aug & Sep & Oct & Nov & Dec \\
\hline Days & 8 & 11 & 5 & 1 & 3 & 14 \\
\hline Max wind speed, m/s & 17 & 20 & 13 & 14 & 10 & 12 \\
\hline Average wind speed, m/s & 9.2 & 7.7 & 7.4 & 7.4 & 4.3 & 6.3 \\
\hline
\end{tabular}

In HYSPLIT dust module, $\mathrm{PM}_{10}$ dust injections are estimated using as mass source algorithm [18].

$$
F=K \frac{\rho}{g} u_{*}\left(u_{*}^{2}-u_{* t}^{2}\right)
$$

where is the vertical mass flux of dust that is obtained from the friction velocity $u_{*}$, a threshold friction velocity $u_{*+}$, (required for initiation of dust emission), and a coefficient $K(\mathrm{~s} / \mathrm{m})$ that depends on the surface soil texture. The friction velocity varies in space and time. However, the threshold velocity and soil texture coefficient vary only in space and related to the soil, land-use characteristics and surface roughness. In this study, the model is used over domain where detailed soil characteristics are not available and revised version of the dust module for vertical mass flux is replaced as Equation (1) [27].

$$
F=0.01 u_{*}^{4}
$$

The trajectory calculation in any Lagrangian model is based on the following the particle or puff. Therefore, once the basic meteorological data $(\mathrm{U}, \mathrm{V}$ and $\mathrm{W})$ has been processed and interpolated to the model grid. Trajectories can be computed to test the advection components of the model. The advection is computed from the average of the 3-D velocity vectors for the initial position $\mathrm{P}(\mathrm{t})$ and the first-guess position 
$\mathrm{P}^{\prime}(\mathrm{t}+\Delta \mathrm{t})$.

The velocity vectors are linearly interpolated in both space and time $[9,10]$.

The first guess position is

$$
P^{\prime}(t+\Delta t)=P(t)+V(P, t) \Delta t
$$

and the final position is

$P(t+\Delta t)=P(t)+0.5\left[V(P, t)+V\left(P^{\prime}, t+\Delta t\right)\right] \Delta t(4)$
In this study forward trajectory simulations were used for determining the dispersion of white dust and motion direction of the dust plume over tailings pond. Forward trajectories started from tailings pond $\left(49.09^{\circ} \mathrm{N}, 104.13^{\circ} \mathrm{E}\right)$. For HYSPLIT trajectory setting, trajectory tracking levels, including 500, 1000 and 1500 $\mathrm{m}$ is considered and also the top of the model assumed to be $10,000 \mathrm{~m}$. Turbulence, wind fields and mixing depth values are used as inputs for dispersion model.

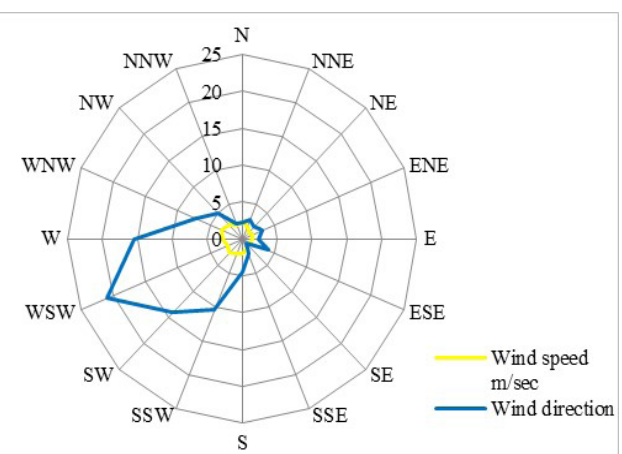

Fig. 3. Polar graph showing the relative impact of the wind, according to azimuth

months to the east and southeast are distributed (Fig.4, 5).

In figure 6 , we can see the graphic of some data of white dust dispersion, air humidity, precipitation and wind speed. For building this graph, we used the data of those days in which the highest wind speed of each month during 2015. In October, white dust has spread far from the tailings pond where no precipitation, low air humidity and wind speed is $14 \mathrm{~m} / \mathrm{s}$. Also in August was windy day (wind speed is $20 \mathrm{~m} / \mathrm{s}$ ), but air humidity was with $66 \%$ due to rain $(22 \mathrm{~mm})$. Therefore, white dust has spread near from the tailings pond. 

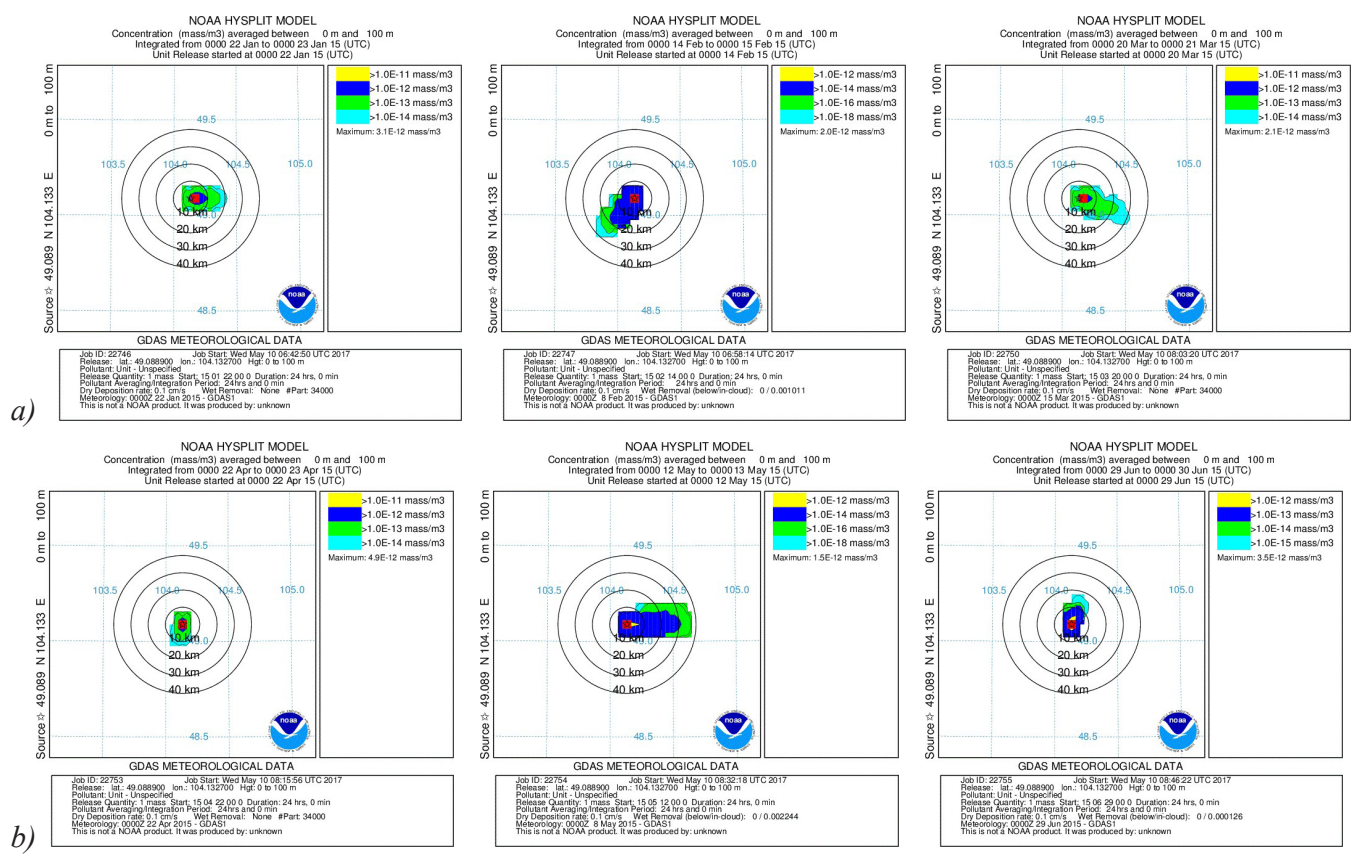

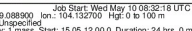
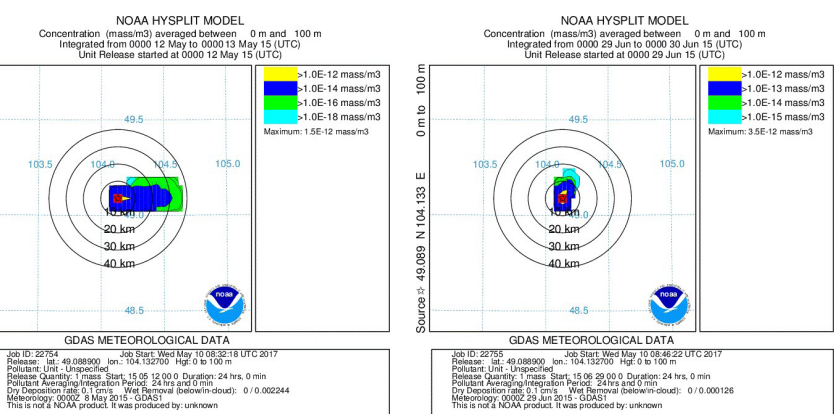

Fig. 4. HYSPLIT-Dispersion generated dust deposition ( $\mu \mathrm{g} \mathrm{m}$-2) averaged between 0 and $100 \mathrm{~m}$ levels and integrated for 24-h period between 0900 UTC of 22 January 2015 and 0900 UTC of 29 June 2015 sourced from tailings pond (49.09N 104.13E), ( a) January-March; b) April-June)
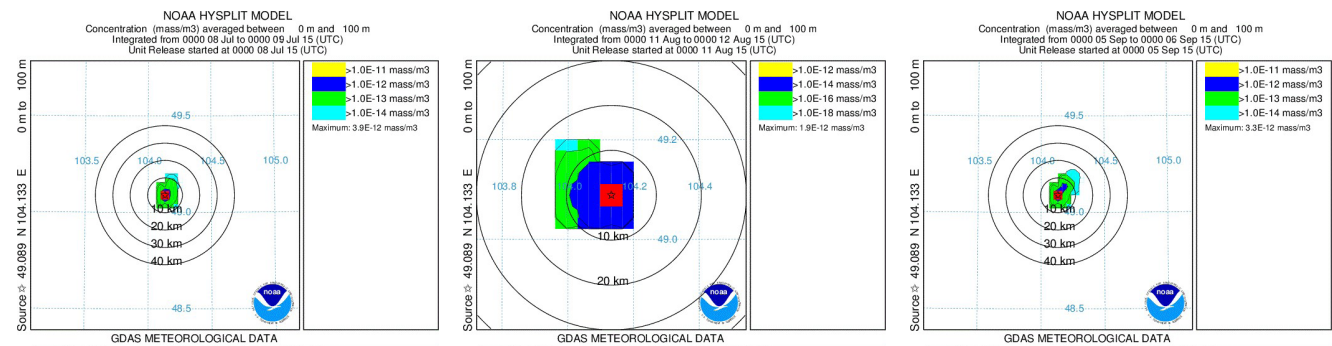

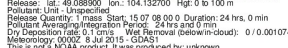

a)

NOAA HYSPLIT MODEL

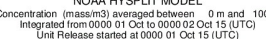

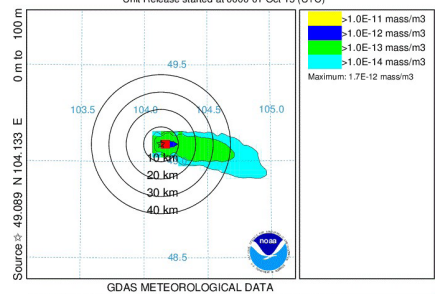

b)

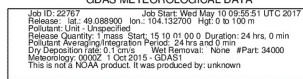

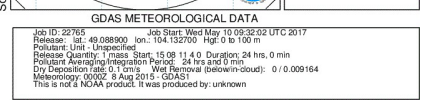

NOAA HYSPLIT MODEL

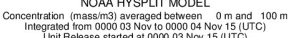

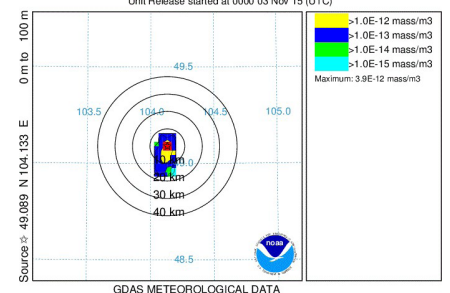

GDAS METEOROLOGICALDATA

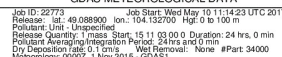

GDAS METEOROLOGICAL DATA

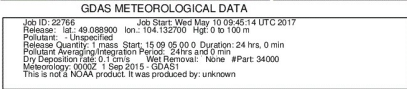

NOAA HYSPLIT MODE

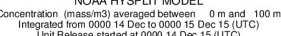

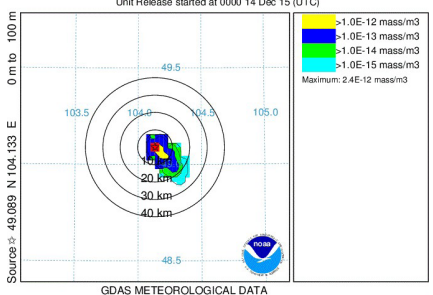

GDAS METEOROLOGICALDATA

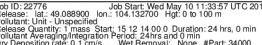

Fig. 5. HYSPLIT-Dispersion generated dust deposition ( $\mu \mathrm{g} \mathrm{m}$-2) averaged between 0 and $100 \mathrm{~m}$ levels and integrated for 24-h period between 0900 UTC of 01 July 2015 and 0900 UTC of 01 December 2015 sourced from tailings pond (49.09N 104.13E), ( a) July-September, b) October-December) 
In figure 7 we can see HYSPLIT-Dispersion and HYSPLIT-Trajectory modeling it showed the white dust possible spread directions and a long distance (Fig.7). On October $1^{\text {st }}$ white dust which erupts into air was reached up 2000 $\mathrm{m}$. It shows that the dust particle size up to $20 \mu \mathrm{m}$ in the air mass has been transferred to the air for a long time. Also on August $11^{\text {th }} 08$ UTC when white dust which erupts into air has been landing on soil sharply, and it shows that it is raining.

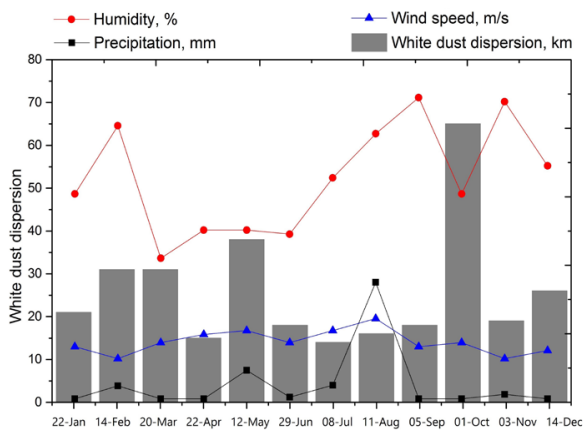

Fig. 6. White dust dispersion
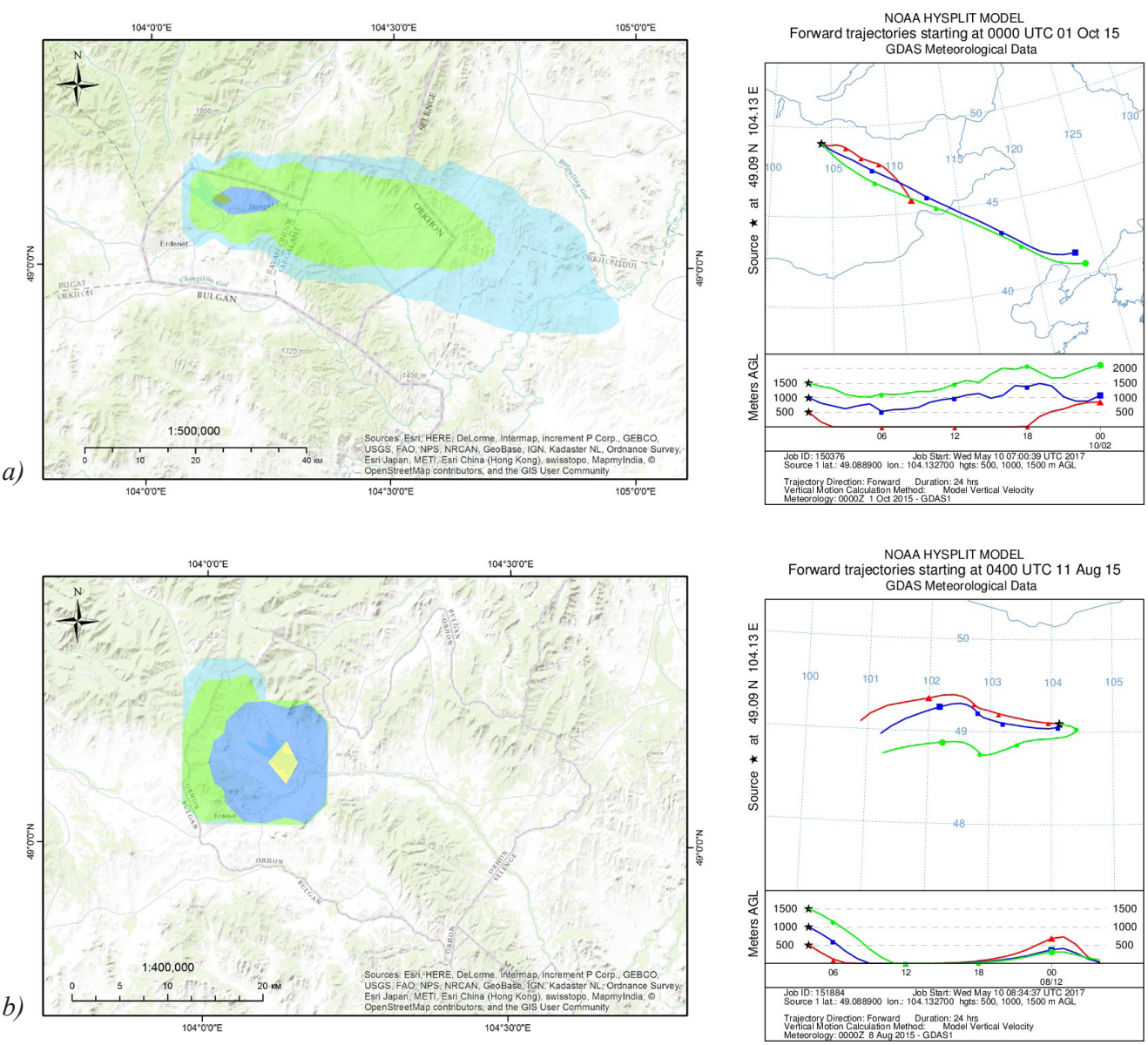

Fig. 7. HYSPLIT-Dispersion and Forward trajectory simulations.

Integrated for 24-h period 0000 UTC of 01 October and 0400 UTC of 11 April 2015 sourced from the tailings pond $(49.09 \mathrm{~N} 104.13 \mathrm{E}$ (a) dry day; b) rainy day 


\section{CONCLUSION}

According to the simulation from model HYSPLIT, white dust was spread between 14 and $65 \mathrm{~km}$ in 2015. During May and October, white dust distribution would increase up to $38-68 \mathrm{~km}$ also these months are the most spread months among all other months.

In May and October are the main months of white dust distribution. During this time, mass concentration of $\mathrm{PM}_{10}$ was measured the highest in ambient air quality. Thereby, it's possible that white dust is the source of $\mathrm{PM}_{10}$.

Comparing the white dust dispersion to

\section{Acknowledgements}

The authors are grateful to anonymous reviewers for their constructive comments. This research is supported by the Mongolian Foundation for Science and Technology of weather factor, it is related to precipitation, relative humidity and wind speed. From the analysis between rainy day and normal day, white dust distribution was four times lower when the rainy day. Therefore, precipitation is an important indicator that white dust spread.

From this simulation and analysis we studied, that the rainfall might be one of the solutions also improving researching on this subject and using it for decreasing the distribution of white dust.

the Ministry of Education, Culture, Science and Sports of Mongolia are gratefully acknowledged. 


\section{REFERENCES}

1. Alam, K., Qureshi, S., Blaschke, T: Monitoring Spatio-temporal aerosol patterns over Pakistan based on MODIS, TOMS and MISR satellite data and a HYSPLIT model. Atmos Environ, 45:4641-4651, 2011

2. Alastuey, A., Querol, X., Castillo, S., Escudero, M., Avila, A., Cuevas, E., Torres, C., Romero, P.M, Exposito, F., Garcia, O., Diaz, J.P, Dingenen, R.V, Putaud, J.P: Characterization of TSP and PM2.5 At izanea and Sta. Cruz de Tenerife (Canary Islands, Spain) during a Saharan dust episode (July 2002). Atmos Environ, 39(26):4715-4728, 2005

3. Challa, V.S, Indrcanti, J., Baham, J.M, Patrick, C., Rabarison, M.K, Young, J.H, Hughes, R., Swanier, S.J, Hardy, M.G: Sensitivity of atmospheric dispersion simulations by HYSPLIT to the meteorological predictions from a meso-scale model. Environ Fluid Mech, 8(4):387-367. Trajectories 4 user's guide. NOAA Tech. Memo, ERL-ARL, 2008

4. Chan, Y.C, Mctainsh, G., Leys, J., Mcgowan, H., and Tews, K: Influence of the 23 October 2002 Dust Storm on the Air Quality of Four Australian Cities, Water. Air. Soil Pollut., 164, 329-348, doi:10.1007/s11270-005-4009-0, 2005

5. Charles, J.T, Gerald, G., Bruce, B., Don, B., Devon, W., and Helene, G: Offsite Impacts of Erdenet Copper Molybdenum Mine Tailings, North Central Mongolia, Oglala Lakota College, USA, 2009

6. Dentener, F.J, Carmichael, G.R, Zhang, Y., Lelieveld, J., and Crutzen, P.J: Role of mineral aerosol as a reactive surface in the global troposphere, J. Geophys. Res. Atmospheres., 101, 22869-22889, doi: 10.1029/96JD01818, 1996

7. Dickerson, R., Kondragunta, S., Stenchikov, G., Civerolo, K., Doddridge, B., and Holben, B: The impact of aerosols on solar ultraviolet radiation and photochemical smog. Science, 278:827-830, 1997

8. Draxler, R., Gillette, A., Kirkpatrick, S., and Heller, J: Estimating PM10 air concentrations from dust storms in Iraq, Kuwait and Saudi Arabia. Atmos Environ, 35:4315-4330, 2001

9. Draxler, R., Hess, G.D: An overview of the HYSPLIT_4 modeling system for trajectories, dispersion and deposition. Aust Meteorol Mag, 47:295-308, 1998

10. Draxler, R., Stunder, B., Rolph, G., Stein, A., and Taylor, A: Hybrid Single-Particle Lagrangian Integrated. United States: NOAA, 2009

11. Escudero, M.,Stein, A., Draxler, R., Querol, X., Alastuey, A., and Castillo, S: Determination of the contribution of north Africa dust source areas to PM10 concentrations over the central Iberian peninsula using the hybrid single-particle lagrangian integrated trajectory model (HYSPLIT) model. J Geophys Res (111):D06210, DOI: 10.1029/2005JD006395, 2006

12. Gerivani, H., Lashkaripour, G.R, Ghafoori, M., and Jalali, N: The source of dust storm in Iran: A case study based on geological information and rainfall data, Carpathian J. Earth Environ., Sci. 6, 297-308, 2010

13. Griffin, D., and Kellogg, C: Dust storms and their impact on ocean and human health: dust in Earth's atmosphere. Ecohealth, 1:284-295, 2004

14. Haywood, J., and Boucher, O: Estimates of the direct and indirect radiative forcing due to tropospheric aerosols: A review, Rev. Geophys., 38, 513-543, doi: 10.1029/1999RG000078, 2000

15. Khukhuu, P., Jadambaa, N., Mandakhbayar, J., Norov, N., and Buyankhishig, N: Additional study of identify for white dust dispersion, transportation, Nemer International LLC, Ulaanbaatar, Mongolia, 2008

16. Krueger, B., Grassian, V., Cowin, J., and Laskin, A: Heterogeneous chemistry of individual mineral dust particles from different dust source regions: The importance of particle 
mineralogy, Atmos. Environ., 38, 6253-6261, doi:10.1016/j.atmosenv.2004.07.010, 2004

17. Lkhagvajargal, B., and Sonomdagva, Ch: Air quality study in Erdenet city, Manag. Innov. Sci. J., 01, 319-322, 2016

18. Marticorena, B., Bergametti, G., Gillette, D., and Belnap, J: Factors controlling threshold friction velocity in semiarid and arid areas of the United States. J Geophys Res, 102:23,277-23,287, 1997

19. McKendry, I.G, Hacker, J.P, Stull, R., Sakiyama, S., Mignacca, D., and Reid, K: Longrange transport of Asian dust to the Lower Fraser Valley, British Columbia, Canada, J. Geophys. Res. Atmospheres., 106, 18361-18370, doi: 10.1029/2000JD900359, 2001

20. METM: Environmental Statistical Database, Ministry of Environment and Tourism of Mongolia, 2015

21. Mongolian Statistical Year Book: National Statistical Office of Mongolia, Ulaanbaatar, Mongolia, 2015

22. Shinn, E.A, Smith, G.Q, Prospero, J.M, Betzer, P., Hayes, M.L, Garrison, V., and Barber, R.T: African dust and the demise of Caribbean Coral Reefs, Geophys. Res. Lett., 27, 3029-3032, doi: 10.1029/2000GL011599, 2000

23. Tegen, I., Hollrig, P., Chin, M., Fung, I., Jacob, D., and Penner, J: Contribution of different aerosol species to the global aerosol extinction optical thickness: Estimates from model results, J. Geophys. Res. Atmospheres., 102, 23895-23915, doi: 10.1029/97JD01864, 1997

24. Viana, M., Pürez, C., Querol, X., Alastuey, A., Nickovic, S., and Baldasano, J.M: Spatial and temporal variability of $P M$ levels and composition in a complex summer atmospheric scenario in Barcelona (NE Spain), Atmos. Environ., 39, 5343-5361, doi:10.1016/j. atmosenv.2005.05.039, 2005

25. Wang, W., Fang, Z.Y: Numerical simulation and synoptic analysis of dust emission and transport in East Asia. Glob Planet Chang, 52:57-70, 2006

26. Wang, Y., Zhuang, G., Tang, A., Zhang, W., Sun, Y., Wang, Z., and An, Z: The evolution of chemical components of aerosols at five monitoring sites of China during dust storms, Atmos. Environ., 41, 1091-1106, oi:10.1016/j.atmosenv.2006.09.015, 2007

27. Westphal, L., Toon, O.B, Carlson, T.N: A two-dimensional numerical investigation of the dynamics and microphysics of Saharan dust storms. J Geophys Res, 92(3):3027-3049, 1987

28. Xuan, J: Emission inventory of eight elements, $\mathrm{Fe}, \mathrm{Al}, \mathrm{K}, \mathrm{Mg}, \mathrm{Mn}, \mathrm{Na}, \mathrm{Ca}$ and Ti, in dust source region of East Asia. Atmos Environ, 39:813-821, 2005

29. Zev, L., Eliezer, G., Victor, G.R, and Beverly, S: The Effects of Desert Particles Coated with Sulfate on Rain Formation in the Eastern Mediterranean, J. Appl. Meteorol. Climatol., 35, 1511-1523, doi:10.1175/1520-0450, 1996 